Paper received: July $3^{\text {rd }} 2015$

Paper accepted: October $22^{\text {nd }} 2015$

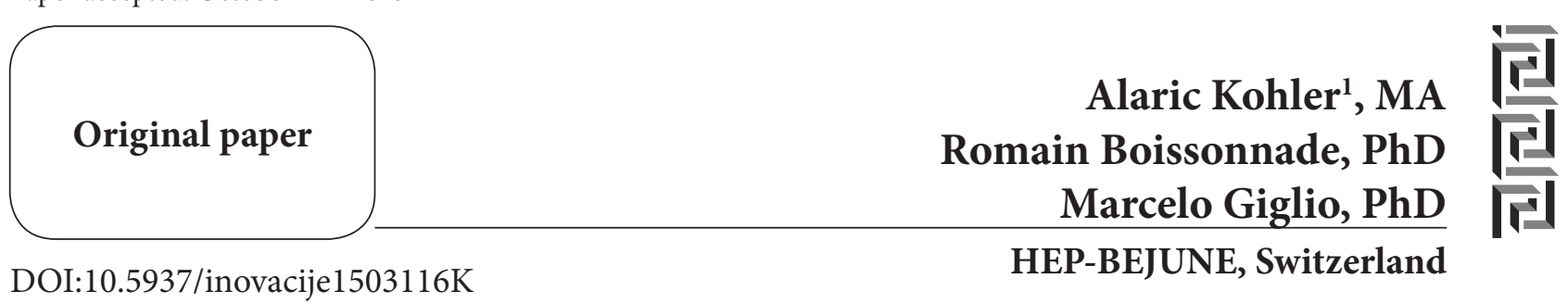

\title{
From innovative teacher education to creative pedagogical designs
}

\begin{abstract}
This contribution is about the design of innovative teaching practices. Innovation is fostered by a focus on creative tasks for school pupils, and supported by teacher education courses. Two examples of teacher education practice are presented, both requiring from student teachers to produce innovative pedagogical designs. A pedagogical design is defined by a specific set of tasks, by a social setting and by a sequence. The first example requires pedagogical designs offering a thinking space to learners, while the second example is based on an iterative research methodology (PIO).

The discussion of these two examples stresses two features of these practices, that can be considered supporting creativity and agency in classroom activities: the anticipation and confrontation between prediction and observation, and the articultion of collective and solitary moments of work in specific sequences. Future research could investigate the potential support the various combinations of collective and solitary moments of activity offer to creativity. These combinations can be designed for teaching practices to fit specific pedagogical and learning objectives, and can be evaluated through micro-design research.
\end{abstract}

Key words: creativity, collaboration, innovation, pedagogical design, teacher education.

\section{Introduction}

In this paper, we examine the potential for encouraging innovative school practices through pedagogical design, building on a few elements from the literature on creativity. Teachers are invited to design lessons for their pupils in elementary or secondary schools which focus on creative tasks. Still, the teachers' activity consisting in designing their teaching is also a creative task which can be used in teacher education for encouraging innovative teaching practices. To differentiate the design by teachers for school, college or high-school, and the courses designed by teacher educators for teacher education, pedagogical design will be reserved to the former. We will illustrate the potential for innovation with two teacher education practices inviting teachers to elaborate and put into practice innovative pedagogical designs including creative school tasks.

1 alaric.kohler@hep-bejune.ch 
The first section of the paper defines briefly creativity and innovation, and stresses the importance of creativity for future school practices. The next section examines the articulation between innovation and design, and sketches the potential of pedagogical and teacher education designs for new practices in teaching. The third section is dedicated to the presentation of two teacher education designs illustrating the potential for innovative teaching practices. The fourth and last section is a critical discussion of both designs presented in the paper, stressing a few relevant elements for fostering creative involvment of students or pupils.

\section{Creativity for innovative teaching practices}

What can be considered innovative in teaching? Recent educational changes in various countries have associated pedagogical innovations with cross-curricular competencies, such as social and communicative skills, meta-cognitive skills, reasoning and creative thinking. The new cross-curricular competencies are developed simultaneously to domain-specific knowledge and skills. For instance, a pupil writing a new text, drawing a picture, composing music, or solving a problem has the opportunity to learn domain-specific content and to develop cross-curricular competencies. Given that the general cross-curricular competencies such as "creative thinking" are rarely the main focus of teaching practices at school, teaching practice focusing on crosscurricular competencies can be considered innovative. Indeed, innovation can be defined as new ideas, products or practices by an individual or group within a specific social system (Rogers \& Shoemaker, 1971). The fact that teaching practices focusing on cross-curricular competencies are often considered a challenge for pupils, teachers, teacher educators and researchers, leads us to consider the development of such teaching practices an innovation.

Among the various cross-curricular competencies, we will focus in this paper on creative thinking, or creativity. The definition of creativity is relative to a specific field or context (Amabile, 1993/1996; Gardner, 2001; Mayer, 1999), which determines what is novel and relevant. Yet, creativity also refers to a psychological process, related to play, imagination, fantasy, feelings and emotions, meaning making and the use of symbols (Vygotsky, 1925/1971; John-Steiner et al., 2010). In addition to the individual psychological approach to creativity, various creative practices can be investigated as collective, as part of collaborative, communicative, and cultural practices. Inspired from previous studies (Miell \& Littleton, 2008; Moran \& John-Steiner, 2004; Sawyer, 2008), we will discuss more specifically the link between collaboration and creativity (Giglio, 2014). Collaborative tasks often involve the production of new ideas. These new ideas can be considered learning gains, or considered only as a production (Giglio \& Perret-Clermont, 2010). Teachers can attempt to design their lessons in a way that learners confront their ideas in a creative way. Yet, teachers need to design the pupil's tasks specifically to foster both creativity and learning (Vygotsky, 1925/1971; 1930/2004; 1931/1994). Research on the socio-cognitive conflict shows that such situations of confrontation of ideas among peers can be beneficial for learning, under certain specific conditions (Perret-Clermont, 1980; Doise \& Mugny, 1981; Littleton \& Howe, 2010), and even when none of the peers have succeeded in the task individually before the interaction (Schwarz et al., 2008).

\section{Developing innovative teaching practices within teacher education}

How can we foster innovation by teachers, in particular in the objective of developing cross-curricular competencies such as creativity and collaboration? Focusing pedagogical designs on creativity is obviously not sufficient to bring innovation in teaching practices. The systematic program of research about the social psychology of creativity by 
Simonton (1997) shows the potential influences of history, culture, society, and biographic conditions on creative production. The intention governing a design can be forgotten, ignored or misunderstood by teachers and pupils when performing the actual activities, revealing a gap between the pedagogical intentions and the practices (Berman et al., 1991; Giglio et al., 2014). There are various ways to foster innovation. Cros (1996) distinguishes between innovation as education and reform, stating that innovation emerges bottom-up from practitioners, while reform is generally imposed by authorities and governments, leading to a well-known resistance and transformation of the initial intentions. Our approach to innovation is educational: It consists in offering opportunities to student teachers ${ }^{2}$ for designing and putting into practice new ways of teaching, based on their own choices and preferences.

The long-term objective of this approach is to offer creative workplaces which can become innovative workforces involving multi-levels collaborations (employee-employers, practitioner-researcher, ...). It is an approach leaning towards social change based on the individual practitioners' creativity which can be used in educational and institutional organizations (Amabile, 1993/1996), which might be expected not to lead to the gap we mentionned above between the pedagogical intentions and the actual new practices. The desired social change is a reciprocal influence between creative experiment in teacher education and teaching experience within school and workplaces situations, which is dialogically impacting the historical and socio-cultural evolution of professional practice in teaching and teacher education. From this perspective we consider it possible to contribute to innovation in teaching with practices in teacher education focusing on creative pedagogical design (Gi-

2 Student teachers refers here to students attending courses and seminars at a teacher education university and simultaneously being supervised during teaching practice at local schools where they are trainees. glio, 2014). In order to develop a dialogue between professional traditions and specific innovations, inviting the individual teachers to participate in defining the content of the innovative practices as well as to engage in their own creative thinking. The focus on pedagogical designs for innovation is an operational choice of this approach to social change because they can become boundary objects (Kohler et al., 2015), if they are collaboratively elaborated and considered relevant to the work practice by the various participants. Pedagogical designs can support innovative teaching because they can function as half-baked objects (Kohler et al., 2015) into which researchers, teacher educators, teachers and pupils engage their creativity when taking it up and modifying it.

In order to offer a space and some resources to student teachers for developing innovative pedagogical designs, we have set teacher education courses or workshops requiring student teachers to elaborate and/or adapt pedagogical designs. The pedagogical designs elaborated by the student teachers should, in turn, offer opportunities for school pupils to engage into creative school task.

\section{Two examples of teacher education practice fostering innovation by student teachers}

A few theoretical elements have been presented which have inspired the work on pedagogical designs and the focus on creativity. We will now present two examples of teacher education practice made for offering space and resources to student teachers to develop innovative pedagogical designs based on creativity. For each example of practice we will describe the tasks proposed to the students by the teacher educator, the settings and the sequence. 


\section{First example: Developing pedagogical design offering a thinking space}

The teacher education practice presented here is inspired by Perret-Clermont's work on the notion of thinking space (Perret-Clermont, 1991, 2001; Psaltis et al., 2015) and was elaborated in 2013 for student teachers, working in the capacity of trainees in secondary schools, college or high-schools/ vocational schools. It is briefly presented below and followed by one example of the educational design elaborated by the students.

The course was spread over a full academic year and consisted of nine sessions, 3 hours each, with 15 to 20 student teachers from various domains (French, geography, history, arts, science...). The main task is to elaborate a pedagogical design offering a thinking space (Mehmeti \& Perret-Clermont, 2015). Briefly, it means that the pedagogical design should aim at having school pupils engaging into genuine reasoning, learning or creative thinking. Student teachers were totally free to design their own experimental lesson, both for the domain-specific content, tasks and the pedagogical setting, and were explicitly invited to be creative and innovative, and to avoid the mere repetition of well-known school practices.

In order to provide student teachers with the intentions of such a pedagogical design, and with resources to create one, the first phase of the course consisted in frontal teaching from the teacher educator, reading assignments, collaborative analysis of school materials and tasks, dialogues and plenary discussions. The following themes were more specifically studied ${ }^{3}$, as resources for designing a thinking space:

- the distinction between teaching and learning (Tiberghien, 1997), notably for students to distinguish between their pedagogical in-

3 The concepts and theories taught to the students are not presented here as it would be too long for the present paper. The references are provided for more information. tentions and the effective learning gains of pupils;

- the issue of co-constructing an inter-subjectivity (Grossen, 1988, 1999) between the teacher and the pupils;

- the importance of the construction of the milieu (Brousseau, 1998/2004) for learners to engage into creative thinkingvarious strategies learners can adopt in order to fulfil the tasks they received from the teacher, while avoiding the hard cognitive work required for learning (Perrenoud, 1994);

- the notion of decontextualisation (PerretClermont et al., 1982) to conceptualize the transformation of knowledge due to its transposition into school practices.

Additionally, student teachers were provided with a procedure adapted from the didactic engineering (Artigue, 1990), to support the design and the self-evaluation of their lesson. The procedure consists in four steps, briefly presented below:

1. the preliminary analysis of the context, to which the pedagogical design is addressed, including known issue and challenges for the chosen teaching content;

2 . the a priori analysis of the pedagogical design, which includes the description of the pedagogical design alongside with reasons supporting the designer's choices, in terms of teaching objectives, expected learning gains, and so on;

3 . the experimentation of the pedagogical design, i.e. the experience of putting it into practice;

4. the a posteriori analysis which consists in a discussion of the expectation and choices described in the a priori analysis, in contrast with the experimentation of the pedagogical design and any feed-back from the participants.

At the end of this first phase, student teachers had produced a description of an educational de- 
sign for a 45 minutes lesson in their own teaching domain, including descriptions about their expected outcome.

During the second phase, the student teachers put into practice the lesson they designed in a role-playing activity with the other students and the teacher educator, who were playing the role of school or college pupils. The interpretation of the pupils is supported by a customized choice of two learner's strategies defined on a character sheet, which confronts the pedagogical design to various classical strategies leading pupils to disengage from the activity.

The teacher educator took the role of a teacher and put into practice a first lesson, in order to provide an opportunity for students to practice their pupils' role a first time. The lesson designed by the teacher educator was provided as an example of a pedagogical design offering a thinking space., and was based on research results discussing how to introduce argumentation in science teaching (Leitão, 2000 ; Osborne et al., 2001 ; Schwarz et al., 2003 ; Muller Mirza \& Perret-Clermont, 2009). However, this example was not provided as a model for students to imitate, nor as a recommendation to include argumentation in their pedagogical designs.

After the practice, student teachers received extensive feedback about their lesson based on their experience as pupils, and on their suggestions, critique and comments regarding the given example, and their thoughts from a teacher's and teacher educator's point of view. Drawing from this feedback, student teachers had to submit a report for the evaluation of the course, where they provided a synthetic evaluation of the pedagogical design and recommendations for improving it.

We will now present a brief description of a pedagogical design elaborated by a student teacher during this course. This design is intended for a class in biology at college or high-school.

- The teacher sets the class in groups of 3-4 pupils and provides each group with a large blank paper sheet, a map of the Galapagos islands and many cards with a picture of a bird and a few lines on various species (on which island it is often found, where it nests, what it eats, the difference of colors between male and female, ...). The given task expects the pupils to classify the various species of birds according to criteria freely chosen by the pupils. The classification can be done on the blank sheet, and should represent a treediagram built with a selected criterion for each bifurcation, and with only two branches at each level.

- When ready, each group presents the classification of the various birds and oraly defends their work justifying the choice of criteria, and the level at which the criteria has been used. After all the presentations, a discussion is engaged identifying which group has the best solution. This discussion, as well as the rest of the activity is truly open and the teacher does not bring a final "correct" solution. As the final part of the pedagogical design, the teacher presents various solutions from biologists to the very same task, reproducing scientists' models of these particular bird species at a given time in the history of science. The attention of the pupils is drawn on the specificities of each classification, and not on the supposed-to-be correct and final answer. The method used in 21 st century biology with genetic analysis, is brought into the pupils spontaneous discussion about their work and results.

After trying the pedagogical design in the role-play, the student teachers adapted minor elements of the design (the number of pupils per group, the time left for each phase, some oral instructions) in order for them to use it with a class at college or high-school, a year later. 


\section{Second example: The Predicting, Implementing and Observing method (PIO) for developing pedagogical designs}

The second example of teacher education practice presented below, is based on a method called "PIO: Predicting, Implementing and Observing” (Giglio \& Perret-Clermont, 2012; Giglio, 2015). This method was elaborated within the broader objective to take advantage of the articulation of research and practice in the context of teacher education, following recent studies in social psychology of cognitive development (Perret-Clermont, Carugati \& Oates, 2004), and Activity Theory (Engeström, 1987; Engeström et al., 1999; Damsa \& Ludvigsen, 2011). According to Giglio (2014) when student teachers alternate roles, between practitioner and researcher, it can be beneficial for their professional development and, in particular, it can help them to engage in creating new pedagogical designs.

Creating a new pedagogical design requires from student teachers to anticipate their actions, consider how their roles are changing depending on the setting and tasks, to reflect on the cross-curricular competencies required in the governmental curriculum, to evaluate the pedagogical relationship and to decide how it can help to introduce creative teaching, new tools, etc. PIO combines research methodology, innovative teaching, and professional procedures based on anticipation of what will happen in natural and complex environments. The innovative aspect is supported by the process of confrontation between predictions and observations in PIO, and by the instruction to student teachers to prepare a pedagogical design including a creative task in a small group setting.

In this teacher education course, student teachers had to develop pedagogical designs with the PIO method. The PIO method uses an iterative research methodology: the school practice is filmed and analyzed a first time in order to improve the pedagogical design for a subsequent trial, and so on ${ }^{4}$. This iterative process allows student teachers to gradually consolidate their skills by alternating a researcher and practitioner standpoint. Before each trial, student teachers had to imagine the implementation of the pedagogical design in a real school environment and make predictions about how the design would run in practice, for instance attempting to predict the reactions of their pupils. These predictions were written and later compared to the result of the observations and analysis made on the recorded practice.

The PIO method was used in this course to provide student teachers with a specific procedure to scaffold the task of creating a new pedagogical design. In this sense, the PIO method targets four main objectives:

- To provide teachers students with opportunities to create an innovative pedagogical design while in pre-service education, and collaborate in its making; to elaborated and improve a pedagogical design focused on pupils' creativity or creative thinking;

- To lead student teachers to confront their own predictions about the pedagogical design, with the observations made on the effective teaching they conducted ;

- To contribute to scientific research investigating teaching-learning processes in creative learning settings.

The use of PIO method for the elaboration and improvement of pedagogical designs is documented in a few studies (Giglio \& Perret-Clermont, 2009, 2012), the results of which we briefly present in the next paragraph.

Firstly, teachers consider it possible to focus their teaching on a creative task for pupils, yet they recognize it is complex and sometimes requires reorganizing the classroom. Secondly, some teach-

4 This procedure has some elements in common with the design experiment methodology (Brown, 1992), yet here the iterative process is not used to discuss research hypotheses but rather to improve the teaching design. 
ers stress the difficulty in welcoming the unexpected and to be led by the students' creative processes. Some teachers admit to not being able to refrain from making or creating instead of their pupils. Thirdly, teachers are in general positively surprised that pupils did not encounter the difficulties they expected with certain tasks.

\section{A few guidelines to foster creative pedagogical designs in teacher education}

The pedagogical designs made by student teachers during these two examples of practice in teacher education can constitute an interesting way to initiate innovative forms of teaching in primary or secondary schools. Simultaneously making such pedagogical designs may be considered an innovative form of teacher education. Yet, there are only two examples among many other possibilities which leads us to raise an important question: What is fostering creativity in the two examples proposed earlier in the paper? The next section tries to contribute to answer this question with a few comments.

We have presented two proposals for teacher education, both focusing on the same creative task, which is to elaborate pedagogical designs based on new teaching ideas aiming at innovative teaching practice. The pedagogical designs elaborated by student teachers in these cases are also expected to focus on a creative task for pupils, at any grade. We will now put an emphasis on two specific features which seem to us particularly important for fostering creativity, agency and learning, namely:

1. the process of anticipation;

2. the articulation of collective and solitary moments of work during the creative activity, resulting from the tasks planned in the design.

\section{Innovating by anticipation, prediction and observation}

In both teacher education examples of practice, the psychological process of anticipating a teaching practice by creating a pedagogical design plays an important role for student teachers to engage into a creative process. The procedure supporting the design is both similar and different in the two cases. Yet, both PIO and the adapted didactic engineering require from students to anticipate the practice involved in their own pedagogical design. While PIO requires precise predictions and research data to confront the predictions with observations, the adapted didactic engineering used in the first example focuses on the justification of the engineering choices, based on the analysis of the particular school context, the knowledge-to-be-taught, the tasks, social setting, etc. There is nevertheless also a process of anticipating the teaching practice, and a confrontation to observations, although these are mainly based on the experience of the lesson and on the participants' feedback and production during the lesson, rather than on video recorded data as in PIO.

More specifically to PIO is the iterative process of confronting predictions and observations, which is considered by Giglio and Perret-Clermont (2012) as motivating changes in the teaching practice at three different levels:

- At level 1, because it changes the interactions between the teacher and pupils during the class;

- At level 2, because it changes the interaction between the university of teacher education where a pedagogical design is elaborated, predicted and observed, and the school in which student teachers are putting the pedagogical design into practice;

- At level 3, because it changes the representation of the interaction between research and practice, notably in the way student teachers can take an intermediate position 
between the position of practitioner, of designer and the position of researcher.

\section{Articulating collective and solitary moments}

An important question for teachers when designing a lesson is the following: How to foster interactions between teacher and pupils and between pupils? In order to define a panel of social situations, "collective moments" can be distinguished from "solitary moments", the latter referring to situations where interactions between individuals are reduced to a minimum during an activity (Boissonnade, 2011). There are social and individual psychological processes both in collective and solitary moments. Hence, it is useful to make a clear distinction between the social setting (collective and solitary moments) and the unit of analysis adopted by the researcher (social or individual). This distinction enables us to distinguish solitary and collective moments in a pedagogical design in a similar way to pre-/post-test experimental paradigm, such as the one used for the socio-cognitive conflict theory (Perret-Clermont, 1980). For instance, pre-/posttest experimental design often set an initial and a final solitary moment, with diverse collective moments inbetween. Solitary moments are situated at one side of an interactional continuum, stretching from less interactive moments to more interactive moments. Solitary moments of work should be distinguished from self-regulation, which is also an important process during collective moments, as we can observe in group work intertwined mutual regulations and self-regulations.

This distinction between solitary and collective moments can also help to better comprehend teachers' perspective and field experience. Indeed, teachers often hesitate to set group work, mentioning various difficulties like time constraints, difficulties to manage peer interactions in groups of pupils, or the lack of relevant activities (Gillies \& Boyle, 2010). Moreover, even in good conditions for coop- erative or collaborative interactions, several studies point out poor learning gains, for instance when pupils have no opportunity to discover the tasks individually and to explore it with their individual competencies and knowledge (e.g. Murphy \& Messer, 2000) or when certain social regulations and influences occur, like overconfidence or imitation (e.g. Levin \& Druyan, 1993; Puncochar \& Fox, 2004).

In the first example of teacher education practice, the main phases are thought to imply interactions between a teacher educator and student teachers. Hence, the preliminary phase should help students to define the problem and understand the educator's intent, but also to regulate common understanding and appropriation of ideas. It is also the case in the second phase, which is more collaborative. Indeed role-playing activity is precisely a collaborative task that cannot be done solitary. It is then not just hoping to entice socio-cognitive dynamics among pupils, but directly implying peer interactions from the task assignment. At a higher level, these collaborative interactions enhance participation and involvement of students in a trial to redefine the teacher's role as genuine and innovative rather than normative and reproductive. Social interactions create the potential for deep changes in the individual representations. In this sense, collaboration can also be considered of educational value, i.e. as a directing force organizing the inter-individual actions and interactions in situation, opening possibilities for the students to think about their future profession as collaborative creation rather than as isolated pedagogical action.

In the second pedagogical design, several interactional levels are implemented including teachers and pupils, but also researchers and students. The interactions are thought to provoke a creative effort and commitment of student teachers in order to develop their own creative pedagogical design with pupils. The predictions and observations of a pedagogical design could be realized by one student as well as a small group or a whole classroom: 
here, collaboration is not defining a kind of activity. But it is important to remember that predicting is not a purely rational activity, made of logical operations. It is a complex activity based also on perceptions, intuitions, feelings, imagination, combination and differentiation of past experiences, all of which are difficult to focus and share in a common discussion. Hence, it can be important to plan variations in the social setting of this task, and distinguish moments where student teachers make their own predictions separately, and moments where they predict in groups. The psychological means could be diverse, relatively to the actual social situation. In a rather different field (physics education), Boissonnade (2011) observed that a combination of moments, first "solitary", second "dyadic", and third "solitary" again, was a more efficient sequence to support predictions of $10 \mathrm{y}$. o. children. Concerning the second example of teacher education practice, we propose to develop it with a sequence alternating solitary with collective moments of work.

\section{A proposal for further research}

The distinction between collective and solitary moments in a pedagogical design motivates a more detailed analysis of the so-called social interactions. Indeed, social interactions are, at a finer level of analysis, made of micro-moments of joined attention and actions, interposed with micro-moments of self-driven attention and individual actions (short intervals where interactions are suspended, where each students think on their own, echoing the previous words, anticipating the next interactions or actions, and connecting themselves with their own past experiences and feelings, defining their personal positions about the problem, maybe writing notes on a sheet of paper in order to focus on and re-en- gage a joined attention to the discourse or activity). On the other hand, some solitary moments are socially oriented: The prediction of the pupils' behaviour in response to a pedagogical design includes the anticipation of social interactions and draws on previous collective moments of work. Hence, what could be considered frontal teaching and non-interactive, because the teacher is the only one actually producing a discourse, may also be considered a collaborative activity as regard to the social processes (interpreting sentences, imagining the educator's intentions,...) that are concomitant to the individual processes (attention, memorizing, ...) , and as regard to the co-regulation of the co-construction of mutual understanding by the whole class.

This discussion illustrates a potential new area for research, investigating the use and combination of solitary and collective moments in pedagogical design and practice. Moments of solitary activity can be planned to foster the appropriation of a thinking space, to improve a pedagogical design or to choose a personal stance on the problem in the current temporal and material constraints, while the interposed collective moments provide a social meaning, a shared orientation of the activity, and useful feed-back to reflect on the personal appropriation and stance. The articulation of these various moments can be the focus of further research, investigating how specific pedagogical designs support pupils' creativity and agency at the level of micro-design.

Future research could investigate the potential support to creativity offered by the various combinations of collective and solitary moments of activity. These combinations can be designed for the teaching practice to fit specific pedagogical and learning objectives, and can be evaluated through micro-design research. 


\section{References}

- Amabile, T. M. (1993/1996). Creativity in Context. Boulder: Westview Press.

- Artigue, M. (1990). Ingénierie didactique. Recherches en Didactique des Mathématiques, 9, 281-308.

- Berman, L. M., Hultgren, F. H., Lee, D., Rivkin, M. S., \& Roderick, J. A. (1991). Toward curriculum for being. Albany, NY: State University of New York Press.

- Boissonnade, R. (2011). Apprendre et raisonner: approche développementale et socio-cognitive du rôle des situations collectives et individuelles d’apprentissage. Thèse de doctorat, Université de Neuchâtel Faculté des Lettres et Sciences Humaines \& Université de Toulouse.

- Brousseau, G. (1998/2004). Théorie des situations didactiques. Grenoble: La Pensée Sauvage.

- Brown, A. L. (1992). Design Experiment: Theoretical and Methodological Challenges in Creating Complex Interventions in Classroom Settings. The Journal of the Learning Sciences, 2, 141-178.

- Cros, F. (1996). Définitions et fonctions de l'innovation pédagogique. Le cas de la France de 1060 à 1994. In M. Bonami \& M. Garant (Eds.), Systèmes scolaires et pilotage de l'innovation. Émergence et implantation du changement (pp. 15-31). Bruxelles: De Boeck.

- Damsa, C.-I., \& Ludvigsen, S. R. (2011). Learning through collaborative creation of knowledge objects in teacher education. International Conference of Computer-supported Collaborative Learning (July).

- Doise, W., \& Mugny, G. (1981). Le développement social de l'intelligence. Paris: Interéditions.

- Engeström, Y. (1987). Learning by expanding: An activity-theoretical approach to developmental research. Helsiniki: Orienta-Konsultit.

- Engeströn, Y., Riettiner, R., \& Punamäki, R.-L. (Eds.) (1999). Perspectives on activity theory. Cambridge: Cambridge University Press.

- Gardner, H. (2001). La inteligencia reformulada: las inteligencias múltiples en el siglo XXI. Barcelona: Paidós.

- Giglio, M. (2014). Five dimensions to study teacher education change for improving musical creative learning. Journal for Educators, Teachers \& Trainers, 5(1), 80-89.

- Giglio, M. (2015). Creative Collaboration in Teaching. Basingstoke, New York, NY: Palgrave MacMillan.

- Giglio, M., \& Perret-Clermont, A.-N. (2009). Lacte créatif au cour de l'apprentissage. Enjeux pédagogiques, $13,16-17$.

- Giglio, M., \& Perret-Clermont, A.-N. (2010). A teaching sequence granting space to the students' collaborative creation in the music classroom: Some observations. In G. Mota \& A. Yin (Eds.), Proceeding of the 23rd International Seminar on Research in Music Education (pp. 96-101). Changchun: North East Normal University.

- Giglio, M., \& Perret-Clermont, A.-N. (2012). Prédire, agir, observer. Une méthodologie pour développer séquences pédagogiques et savoirs professionnels. Pratiques de recherche dans les institutions de formation des enseignant-e-s, 14, 127-140.

- Giglio, M., Matthey, M.-P., \& Melfi, G. (2014). Réactions des formateurs d'enseignants à un nouveau curriculum scolaire. Bienne: Ed. HEP-BEJUNE.

- Gillies, R., \& Boyle, M. (2010). Teachers' reflections on cooperative learning: Issues of implementation. Teaching \& Teacher Education, 26(4), 933-940. 
- Grossen, M. (1988). L'intersubjectivité en situation de test. Cousset: Delval.

- Grossen, M. (1999). Approche dialogique des processus de transmission-acquisition de savoirs. Une brève introduction. Actualités psychologiques, 7, 1-32.

- John-Steiner, V. P., Connery, M. C., \& Marjanovic-Shane, A. (2010). Dancing with the Muses: An Culturalhistorical Approach To Play, Meaning Making and Creativity. In M. A. Connery, V. P. John-Steiner, \& A. Marjanovic-Shane (Eds.), Vygotsky and Creativity. A Cultural-historical Approach to Play, Meaning Making, and the Arts (pp. 3-15). New York, NY: Lang.

- Kohler, A., Chabloz, B., \& Perret-Clermont, A.-N. (2015). Dispositifs d'enseignement mi-finis: une condition de collaboration entre enseignants et chercheurs? Cahiers de psychologie et éducation (Universitéde Neuchâtel), 51, 5-26.

- Leitão, S. (2000). The potential of argument in knowledge building. Human Development, 43, 332-360.

- Levin, I., \& Druyan, S. (1993). When socio-cognitive transaction among peers fails: The case of misconceptions in science. Child Development, 64, 1571-1591.

- Littleton, K., \& Howe, C. (2010). Educational dialogues: Understanding and promoting productive interaction. London: Routledge.

- Mayer, R. E. (1999). Fifty years of creativity research. In R. J. Sternberg (Ed.), Handbook of creativity (pp. 449460). Cambridge: Cambridge University Press.

- Mehmeti, T., \& Perret-Clermont, A.-N. (2015). Seeking success of migrant students through designed tasks: A case study with Albanian students in Switzerland. In Proceeding of the EARLI 2014 Meeting of the SIG 26 "Dialogue, Argumentation, and Reasoning".

- Miell, D., \& Littleton, K. (2008). Musical collaboration outside school: Processes of negotiation in band rehearsals. International Journal of Educational Research, 47(1), 41-49.

- Moran, S., \& John-Steiner, V. (2004). How collaboration in creative work impacts identity and motivation. In D. Miell \& K. Littleton (Eds.), Collaborative Creativity: Contemporary perspectives (pp. 11-25). London: Free Association Books.

- Muller Mirza, N., \& Perret-Clermont, A.-N., (2009). Argumentation and Education: Theoretical Foundation and Practices. New York, NY: Springer.

- Murphy, N., \& Messer, D. (2000). Differential benefits from scaffolding and children working alone. Educational Psychology, 20, (1), 17-31.

- Osborne, J., Erduran, S., Simon, S., \& Monk, M. (2001). Enhancing the quality of argument in school science. School Science Review, 82, 63-70.

- Perrenoud, P. (1994). Métier délève et sens du travail scolaire. Paris: ESF.

- Perret-Clermont, A.-N. (1980). Social interaction and cognitive development in children. New York, NY: Academic Press.

- Perret-Clermont, A.-N. (1991). La interacción social como espacio de pensamiento. Anthropos: Boletín de información y documentación, 124, 45-47.

- Perret-Clermont, A.-N. (2001). Psychologie sociale de la construction de l'espace de pensée. In J. Ducret (Ed.), Actes du colloque. Constructivisme: usages et perspectives en éducation (pp.65-82). Geneva: Département de l'Instruction Publique, Service de la recherche en Education. 
- Perret-Clermont, A.-N., Brun, J., Conne, F., \& Schubauer-Leoni, M.-L. (1982). Décontextualisation et recontextualisation du savoir dans l'enseignement des mathématiques à de jeunes élèves. Interactions didactiques, 1, 1-33.

- Perret-Clermont, A.-N., Carugati, F., \& Oates, J. (2004). A socio-cognitive perspective on learning and cognitive development. In J. Oates \& A. Grayson (Eds.), Cognitive and language development in children (pp. 305-332). Oxford: Blackwell.

- Psaltis, C., Gillespie, A., \& Perret-Clermont, A.-N. (Eds.) (2015). Social Relations in Human and Societal Development. London: Palgrave MacMillan.

- Puncochar, J. M., \& Fox, P. W. (2004). Confidence in individual and group decision making: When "two heads" are worse than one. Journal of Educational Psychology, 96, 582-591.

- Rogers, E. M., \& Shoemaker, F. F. (1971). Communication of Innovations: A Cross-Cultural Approach. New York, NY: Free Press.

- Sawyer, R. K. (2008). Learning music from collaboration. International Journal of Educational Research, 47(1), 50-59.

- Schwarz, B. B., Neuman, Y., Gil, J., \& Ilya, M. (2003). Construction of collective and individual knowledge in argumentative activity. The Journal of the Learning Sciences, 12, 219-256.

- Schwarz, B. B., Perret-Clermont, A.-N., Trognon, A., \& Marro Clément, P. (2008). Emergent learning in successive activities: Learning in interaction in a laboratory context. Pragmatics and Cognition, 16(1), 57-91.

- Simonton, D. K. (1997). Products, persons, and periods: Histotiometric analyses of compositional creativity. In D. Hargreaves \& A. North (Eds.), The social psychologiy of music (pp. 107-122). Oxford: Oxford University Press.

- Tiberghien, A. (1997). Learning and teaching: Differentiation and relation. Research in Science Education, 27, 359-382.

- Vygotsky, L. S. (1925/1971). The psychology of art. Cambridge, MA: The MIT Press.

- Vygotsky, L. S. (1930/2004). Imagination and creativity in childhood. Journal of Russian and East European Psychology, 42(1), 7-97.

- Vygotsky, L. S. (1931/1994). Imagination and creativity of the adolescent. In R. Van Der Veer \& J. Valsiner (Eds.), The Vygotsky Reader (pp. 266-288). Cambridge-Oxford: Blackwell. 


\section{мср. Аларик Колер}

Универзитет за образовање наставника кантона Берн, Јура и Нојшател, Швајцарска

\section{др Ромен Боасонад}

Универзитет за образовање наставника кантона Берн, Јура и Нојшател, Швајцарска

\section{др Марсело Ђиљо}

Универзитет за образовање наставника кантона Берн, Јура и Нојшател, Швајцарска

\section{Од иновативног образовања наставника до креативних педагошких пројеката}

Скорашње образовне промене у различитим земљама су повезале педагошке иновације са кроскурикуларним компетенцијама, као што су социјалне и комуникативне вештине, метакогнитивне вештине, резоновање и креативно размишљање. Ове компетенције су ретко главни фокус поучавања у школи, што нас наводи да узмемо у обзир сваку врсту поучавања које се сматра „иновативним“. Заправо, „иновација“ може да се дефинише као нове идеје, производи или пракса појединца или групе у оквиру посебног социјалног система (Rogers \& Shoemaker, 1971). Међу различитим крос-курикуларним компетенцијама, у овом раду ћемо се усредсредити на „креативно мишљење“ или на „размишљање“. Усредсређивање на педагошке пројекте у вези са креативношћу очигледно није довољно да би се иновације увеле у процес поучавања. У току извођења планираних активности наставници и ученици могу да забораве, занемаре или погрешно протумаче намеру са којом се води пројекат. Образовање наставника је домен праксе где постоји потреба да се успостави дијалог између професионалне традиције и иновације. Да би се допринело успостављању овог дијалога, у овом раду су представљена два примера праксе образовања наставника да би се направио простор и подлога за ученике и наставнике да развијају иновативне педагошке пројекте, засноване на креативности. Педагошки пројекти које су развили ученици и наставници могу заузврат да понуде ученицима могућност за посредовање, сарадњу и креативност.

Први часови праксе учитеља састојали се из израде „педагошког пројекта који нуди простор за размишљање“ (Mehmeti \& Perret-Clermont, 2015). Требало је да студенти, будући наставници, осмислие час кроз активност игре улога са другим студентима и професором тако да сви имају улоге школског или факултетског ученика (студента). Игра улога подржана је специјално направљеним избором две ученицке стратегије, дефинисане листом карактера, а које супротстављају педагошки пројекат различитим класичним стратегијама, наводећи студенте да се искључе из активности. После практичног рада, студенти, односно будући наставници, добијали су повратну информацију о педагошком пројекту, базираном на искуству учесника као ученика, и на њихов предлог, критике и коментаре као наставника и едукатора наставника.

На другом практичном делу коришћена је методологија истраживања „РIO: Predicting, Implementing and Observing“ - „Предвиђање, имплементација и опсервација“ (Giglio \& Perret-Clermont, 2012; Giglio, 2015). Студенти, будући наставници, морали су да развију педагошки пројекат према истраживачкој методологији, предвиђајући како ће у пракси да се одвија пројекат, уграђујући га у реално школско окружење и снимајући податке за анализу, као што су видео-записи одржаног часа. Анализа је сачињена ради побољшања педагошког пројекта за испитивање које следи. Овај процес понављања 
је омогућавао студентима, будућим наставницима, да постепено консолидују своје вештине бивајући наизменично и истраживачи и практичари.

Шта смо научили из ова два примера? Можемо ли да формулишемо смернице које ће покренути креативне педагошке пројекте у образовању наставника? У оба случаја праксе, психолошки процес прихватања поучавања, док се осмишљава игра, има веома битну улогу и за покретање креативног размишљања и посредовања и приликом побољшавања педагошких пројеката. Приликом дискутовања о ова два предлога о образовању наставника, такође наглашавамо посебне „колективне“ и „самосталне“ моменте. На пример, у првом делу, самостални задатак се састоји од прихватања окружења у учионици и подржава га колективна игра по улогама. У другом делу, самостални моменти предвиђања ученичке реакције на пројекат су касније били супротстављени колективној дискусији у вези са пројектом. „Колективни“ и „самостални моменти“ могу да се прихвате као елементи микродизајна, којима могу да се направе различите комбинације како би се подржала креативност и посредовање ученика, то јест ефикасност која може да се процени током даљих истраживања.

Кључне речи: креативно мишљење, колективни момент, самостални момент. 